\title{
Menopause, Hormonal Changes and Osteoporosis among Women in Region of the Western Macedonia
}

\author{
Albulena Beadini ${ }^{1}$, Sheqibe Beadini ${ }^{1}$, Sadi Bexheti ${ }^{1}, \&$ Nexhbedin Beadini $^{1}$ \\ ${ }^{1}$ University of Tetovo, Department of Biomedicine, Faculty of Medical Science, Republic of North Macedonia \\ Correspondence: Albulena Beadini, University of Tetovo, Department of Biomedicine, Faculty of Medical \\ Science, Republic of North Macedonia. E-mail: albulena.beadini1992@gmail.com
}

Received: May 28, 2019

Accepted: June 25, 2019

Online Published: July 10, 2019

doi:10.5539/ijb.v11n4p9

URL: https://doi.org/10.5539/ijb.v11n4p9

\begin{abstract}
Menopause is known as the end of natural transition in a woman's reproductive life. Otherwise, is the period when progesterone and estrogen production is significantly reduced. The ovaries forbid the cell production and woman loses the ability of getting pregnant. Menopause is defined a period after 12 months without a menstrual cycle or even more.

Osteoporosis is defined as bone tissue disorder characterized by loss of bone mass and bone structure disorder, enabling increased risk for fracture and bone fracture in general. Osteoporosis is considered the most prevalent disease around the age of 50 .

The prevalence of this disease on the basis of the most pronounced gender is in females compared to males, respectively a ratio of $3: 1$ (WHO, 2010).

It is known that loss of osteoarthritis occurring in women during premenopausal is related to estrogen deficiency and the lack of hormonal imaging character that occurs in women during menopause and premenopause.

Status of vitamin D plays a key role in bone health and early prevention of vitamin D deficiency disorders of rakitis and osteomalacia are very important but may also have a low vitamin D implication bone loss, muscle weakness and reduced fractures in older people and these are very important in public health issues in terms of morbidity, quality of life and costs for health services.
\end{abstract}

Keywords: Menopause, Osteoporosis, Vitamin D, Parathormone, Calcium, Hormonal Level

\section{Introduction}

Menopause is known as the end of natural transition to a woman's reproductive life. Otherwise, is the period when progesterone and estrogen production is significantly reduced. The ovaries stop producing egg cells and women lose her ability to become pregnant. Menopause is defined after 12 months of stop getting the regular menstrual cycle or even longer (Russo, Gregório, Lacativa, \& Marinheiro, 2009). For more, the loss of the menstrual cycle for a period of 12 months. The average of the menopause in some women is 52 but in some women this age varies.

In some menopausal women symptoms may last for several months or even years, nut with menstrual cycle disorders appear the first signs of menopause. These symptoms can be treated naturally:

- $\quad$ Menstrual cycle disorders

- Vaginal dryness

- $\quad$ Loss of libido

- $\quad$ Body temperature

- Insomnia

- Frequent urination

- Mood changes

- Breast reduction

- $\quad$ Drying of the skin 
- Weight gain

- $\quad$ Damage to the bones

\subsection{Post Menopause}

The period after menopause is known as postmenopause. The postmenopausal period can also be defined based on the analysis of a hormone known as the follicle stimulating hormone (FSH). When the level of follicle stimulating hormone in women is constantly increasing and has not followed the menstrual cycle then it is defines as being in the menopause period (Bandeira et al., 2010).

The symptoms of perimenopause continue in the postmenopausal period. Based on estrogen and progesterone production values affect the sensitivity of chronic inflammation after menopause where women should be treated for heat disease and bone damage (Holick et al., 2011).

\subsection{Diagnosing Menopause}

In many cases, menopause is self-diagnosed with visible changes in body temperature and prolonged menstrual cycle for 12 consecutive months. During the menopause period, exercises and physical activities are recommended to overcome the symptoms of menopause more easily.

1. A buffer test that determines the vaginal $\mathrm{pH}$ - during the vaginal $\mathrm{pH}$ reproductive years is about 4.5 while during menopause it grows around $\mathrm{pH} 6$.

2. The follicle-stimulating hormone during menopause increases and estrogen levels fall. Both of these tests estimate the period of menopause. The follicle-stimulating hormone levels can be measured more than once during the perimenopause period. When menopause is diagnosed, factors such as age, type of menstrual cycle, vaginal $\mathrm{pH}$, and blood are taken into consideration. Because signs and symptoms of menopause may reflect hypothyroidism and thyroid hormone disease. Because of lowering estrogen levels during menopause, there is also increased risk for heart disease, cardiovascular disease and bone loss degeneration.

\section{Osteoporosis}

Osteoporosis is defined as abdominal disorder characterized by loss of bone mass and bone structure disorder, enabling increased risk for fracture and bone fracture in general. Osteoporosis is considered the most prevalent disease around the age of 50 (Wahl et al., 2012).

The prevalence of this disease on the basis of gender is the highest in females compared to males, respectively a ratio of 3:1 (Working group of the Australian and New Zeland, Bone and Mineral Society, 2005).

It is known that loss of bone mass occurring in women during premenopausal is related to estrogen deficiency and the characteristic hormonal imbalance occurring in women during menopausal and premenopausal period (Holick et al., 2011).

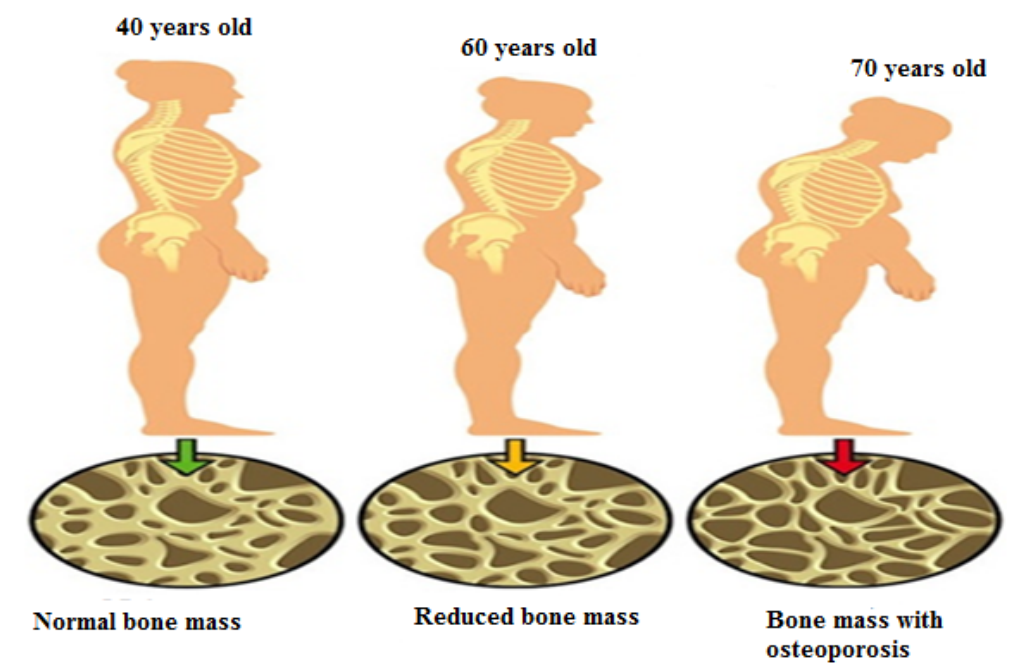

Figure 1. The appearance of osteoporosis in women begins at the age of 40 and increases its intensity until the age of 60 and 70 (Based on WHO health Navigator) 
Mostly in these groups of patients there is also an imbalance of the parathyroid hormones, namely the high level of this hormone that exhibits its action on osteoblasts, causing their aging and death, decreasing vitamin D levels and decreasing $\mathrm{Ca}^{2+}$ levels (Salamone, Dallal, Zantos, Makrauer, \& Dawson-Hughes, 1994).

Vitamin D is a vitamin-soluble lip soluble vitamin that is present in animals, plants and yeast, and vitamin D has many major roles in the human body.

Technically it should be considered as (steroid hormone) because it is synthesized by body (skin) from sunlight (UV rays 290 to $-315 \mathrm{~nm}$ ).

Vitamin D is transported by blood, activated and then acts on specific target tissue receptors or target tissues.

Vitamin D feedback regulation is included by the level of $\mathrm{Ca}^{2+}$ and the active forms of vitamin $\mathrm{D}$.

In 1919, Rakitis was diagnosed as a result of bone deformations in young people and due to the lack of dietary factors and lack of sunlight.

Vitamin D is transmitted through the blood vessels to the body and stops in the liver where it is converted into a prohormone called calcitriol. The circulating calcitriol in the blood is then converted into the active form of vitamin $\mathrm{D}$ in kidney as calcitriol and again released into circulation linked to the vitamin $\mathrm{D}$ and binding proteins, which is transported protein in plasm and is transported in the target organs (IOM (Institute of Medicine), 2011).

In the kidneys, calcitriol can also be synthesized by macrophages - monocytes, in which case it acts as a cytokine to protect the organism against foreign bodies by activating the immune system. Calcitriol is the $1 \alpha, 25$ dihydroxycholecalciferol hormone and steroid hormone involved in regulation of calcium homeostasis which in the kidney is synthesized by calcitriol by hydroxylation in the $\mathrm{C}-1$ carbon atom.

\section{Aim of the Study}

The locomotion system is one of the most important human body systems involving the skeletal system and the muscular system, and the main purpose of this study was to investigate some biochemical and hormonal parameters in patients with osteoporosis diagnosis compared with control patients.

Based on the statistics from the World Health Organization was that the most affected by osteoporosis are women than men, the main reason for this study that we have received more female patients than male patients.

During this study, patients with osteoporosis have been diagnosed with parathyroid hormone, vitamin $\mathrm{D}$ during the winter and summer period and the level of calcium and phosphorus ions that serve as very important indicators in bone metabolism.

\section{Materials and Methods}

This study includes data for 670 female patients, mainly women in premenopausal, menopausal and postmenopausal period. The data were obtained from the Skopje Clinical Laboratory, the Albimedika Laboratory and the Medical Scientific Research Laboratory. In this research are consulted gynecologist, doctor's specialist, endocrinologist, orthopedic specialist.

Samples of researched patients were analyzed for the determination of parathyroid hormone, vitamin $\mathrm{D}$ and $\mathrm{Ca}^{2+}$ in serum. The method of determining the concentration of calcium in the serum is done by specrtophotometric method, whereas the method for determining the concentration of vitamin D and the parathyroid hormone is through the Vidas - immunoassay fluorescent test apparatus. Patients were also analyzed for lipid, glycemic parameters, the body mass index and hypertension.

\section{Results}

Table 1. Results on Vitamin D, Parathormone and calcium ions in women at different periods during summer and winter time

\begin{tabular}{|c|c|c|c|c|c|c|c|c|c|}
\hline \multirow{2}{*}{$\begin{array}{l}\text { Age } \\
\text { groups }\end{array}$} & \multirow{2}{*}{$\begin{array}{l}\text { Vitamin D during } \\
\text { winter time } \\
\text { Normal } \\
\text { values }>\mathbf{3 0} \mathrm{ng} / \mathrm{ml}\end{array}$} & \multirow{2}{*}{$\begin{array}{l}\text { Vitamin D during } \\
\text { summer time } \\
\text { Normal } \\
\text { values }>30 \mathrm{ng} / \mathrm{ml}\end{array}$} & \multicolumn{2}{|c|}{ Calcium $\mathrm{Ca}^{2+}$} & \multicolumn{2}{|c|}{ Parathohormone } & \multicolumn{3}{|c|}{ Control patients } \\
\hline & & & 2.1-2.6 mmo & & $\begin{array}{l}\text { PTH ( } \\
\text { 42pg/mL) }\end{array}$ & $<$ & Vit.D & $\mathrm{Ca}^{2+}$ & PTH \\
\hline 40-45years & $21.5 \mathrm{ng} / \mathrm{ml}$ & $31.7 \mathrm{ng} / \mathrm{ml}$ & Winter & Summer & $82.5 \mathrm{pg} / \mathrm{mL}$ & & $50 \mathrm{ng} / \mathrm{ml}$ & $2.2 \mathrm{mmol} / 1$ & $25 \mathrm{ng} / \mathrm{ml}$ \\
\hline 46-52years & $18.2 \mathrm{ng} / \mathrm{ml}$ & $26.5 \mathrm{ng} / \mathrm{ml}$ & $2.0 \mathrm{mmol} / 1$ & $2.25 \mathrm{mmol} / 1$ & $93.7 \mathrm{pg} / \mathrm{mL}$ & & $48 \mathrm{ng} / \mathrm{ml}$ & $2.4 \mathrm{mmol} / 1$ & $38 \mathrm{ng} / \mathrm{ml}$ \\
\hline \multirow[t]{2}{*}{$\begin{array}{l}53-60 \\
\text { years }\end{array}$} & $15.4 \mathrm{ng} / \mathrm{ml}$ & $20.3 \mathrm{ng} / \mathrm{ml}$ & $1.96 \mathrm{mmol} / 1$ & $2.16 \mathrm{mmol} / 1$ & $98.4 \mathrm{pg} / \mathrm{mL}$ & & $45.5 \mathrm{ng} / \mathrm{ml}$ & $2.6 \mathrm{mmol} / 1$ & $34 \mathrm{ng} / \mathrm{ml}$ \\
\hline & & & $1.92 \mathrm{mmol} / 1$ & $2.05 \mathrm{mmol} / 1$ & & & & & \\
\hline
\end{tabular}


Based on results obtained from researched female patients at different stages of menopause and different age groups we present these results.

Table 2. Results for vitamin $\mathrm{D}$ in women in different periods during winter and summer time and the control patients

\begin{tabular}{llll}
\hline Age groups & Vitamin D- during winter time & Vitamin D- during summer time & Control patients \\
\hline $\mathbf{4 0 - 4 5}$ years & $21.5 \mathrm{ng} / \mathrm{ml}$ & $31.7 \mathrm{ng} / \mathrm{ml}$ & $50 \mathrm{ng} / \mathrm{ml}$ \\
$\mathbf{4 6 - 5 2}$ years & $18.2 \mathrm{ng} / \mathrm{ml}$ & $26.5 \mathrm{ng} / \mathrm{ml}$ & $48 \mathrm{ng} / \mathrm{ml}$ \\
$\mathbf{5 3 - 6 0 y e a r s}$ & $15.4 \mathrm{ng} / \mathrm{ml}$ & $20.3 \mathrm{ng} / \mathrm{ml}$ & $45.5 \mathrm{ng} / \mathrm{ml}$ \\
\hline
\end{tabular}

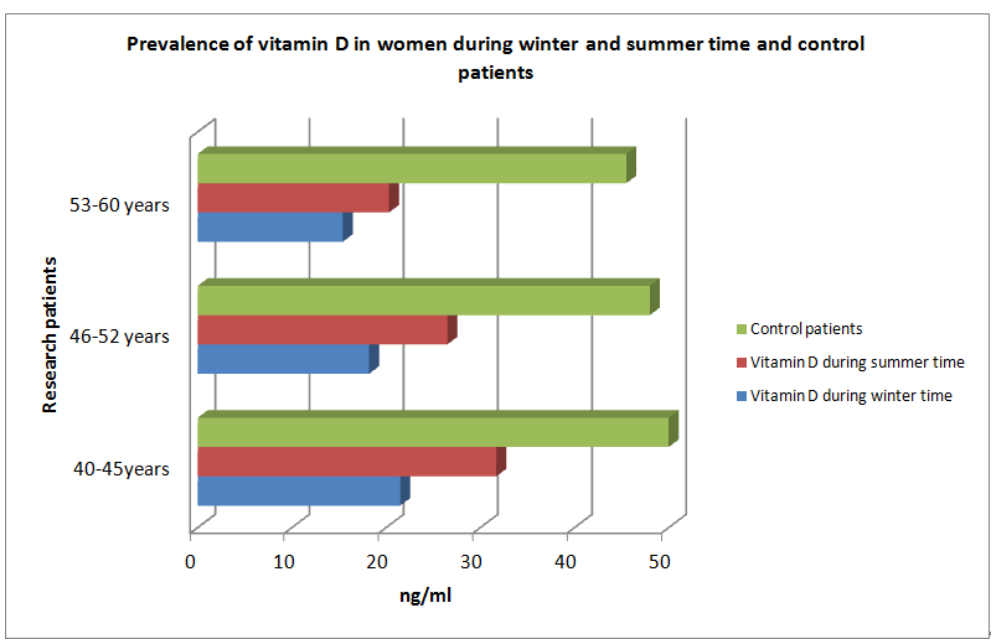

Figure 2. Prevalence of vitamin D in women during winter and summer time and control patients

From the obtained results we conclude that vitamin D level in women in menopausal period is lower than in the control patients and also the vitamin D level compared between winter time and summer time is around $10-15 \%$ lower in winter time.

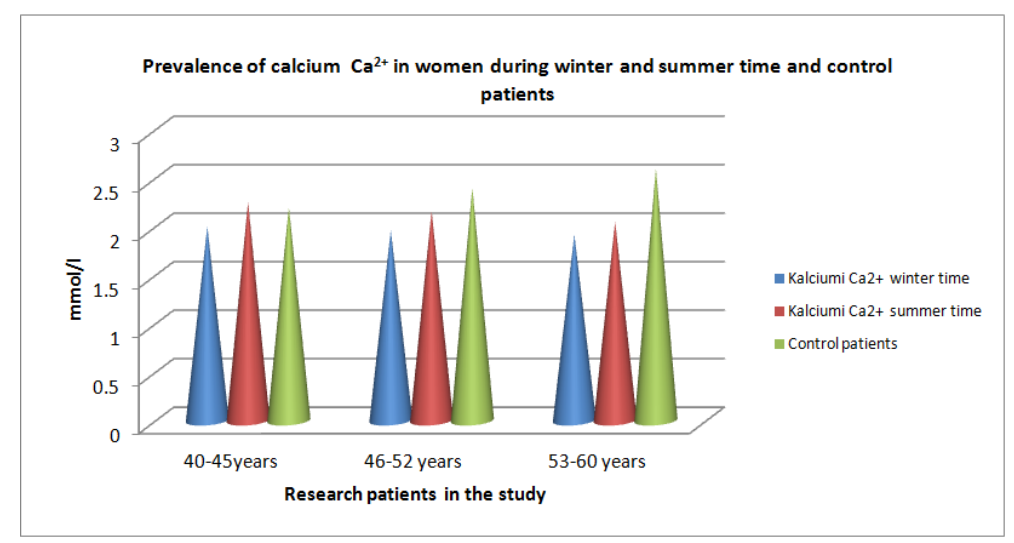

Figure 3.. Prevalence of calcium $\mathrm{Ca}^{2+}$ in women during winter and summer time and control patients

Table 3. Results for parathormone

\begin{tabular}{lll}
\hline Age groups & Parathormone & $\mathbf{C a}^{2+}$ \\
\hline $\mathbf{4 0 - 4 5}$ years & $62.5 \mathrm{pg} / \mathrm{mL}$ & $2.2 \mathrm{mmol} / 1$ \\
$\mathbf{4 6 - 5 2}$ years & $73.4 \mathrm{pg} / \mathrm{mL}$ & $2.0 \mathrm{mmol} / 1$ \\
$\mathbf{5 3 - 6 0}$ years & $84.5 \mathrm{pg} / \mathrm{mL}$ & $1.82 \mathrm{mmol} / 1$ \\
\hline
\end{tabular}


Permanent reduction with a high signaling reduces in progressively way the level of calcium paralysis with the vitamin $\mathrm{D}$ of all age groups investigated in comparison to the control patients.

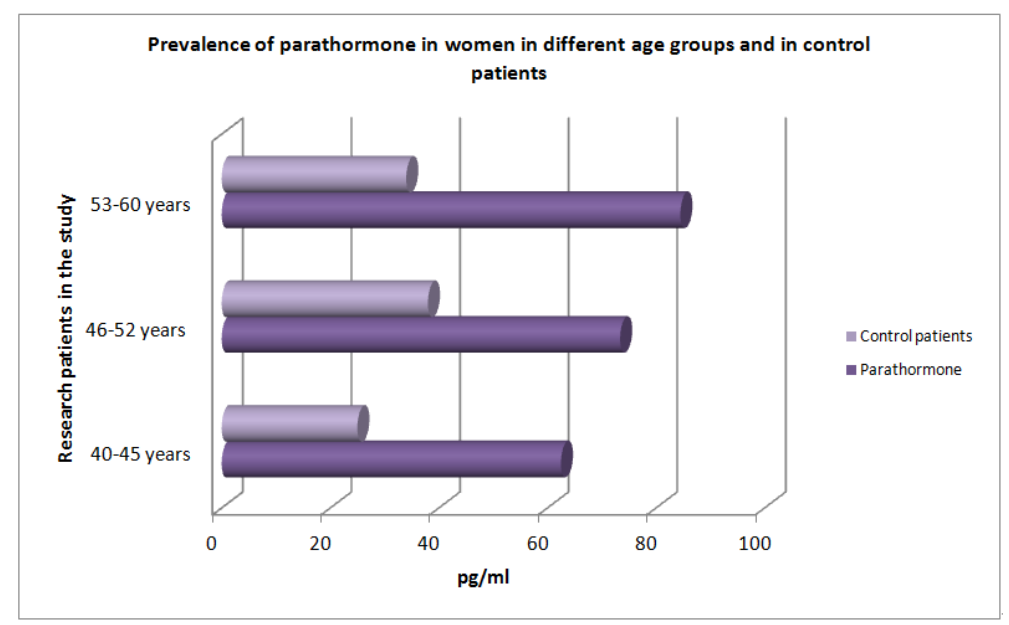

Figure 4. Prevalence of parathormone in women in different age groups and in control patients

Parathyroid hormone is a very important hormone in women who have a $12-15 \%$ increase of parathormone in patients with low level of vitamin D and decrease of calcium ions compared with control patients.

\section{Prevalence of menopausal symptoms and their percentage}

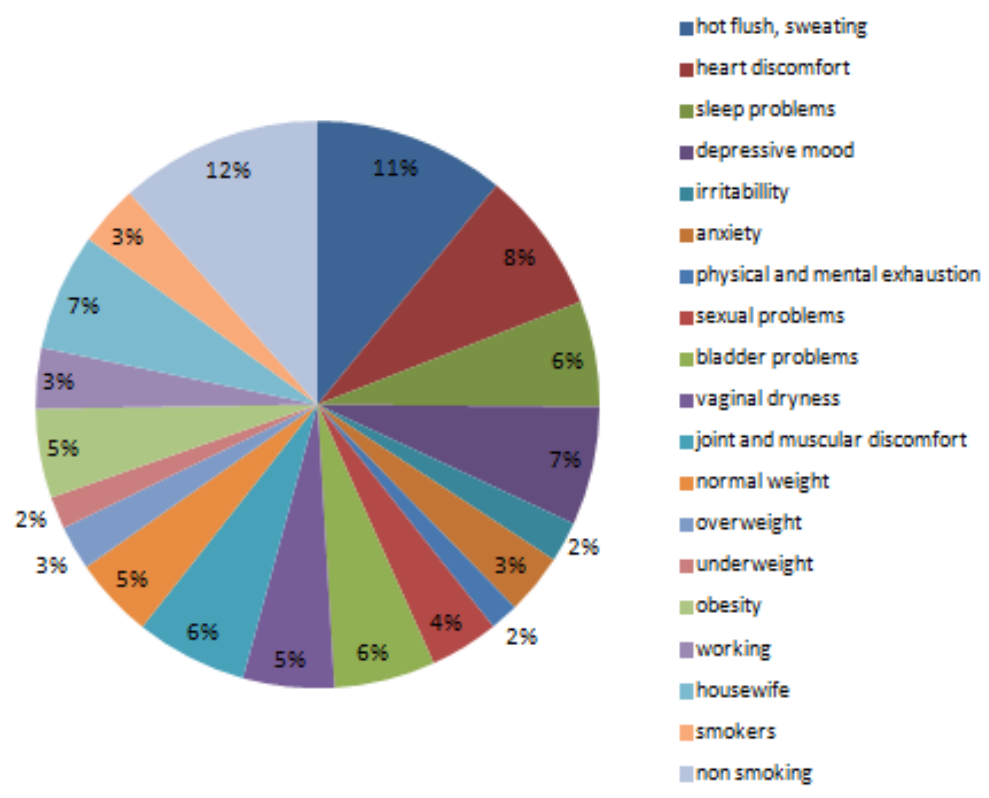

Figure 5. Prevalence of menopausal symptoms and their percentage

From the survey of women in period of premenopause, menopause and postmenopause we conclude that the mo common symptoms are in women with high body temperature. The other symptoms was insomnia, depression, bone pain, muscle pain etc. 


\section{Discussion}

Despite the high social and economic cost of osteoporosis, the use of pharmacological interventions to prevent fractures has dropped significantly the last years.

In 2010, 22 million of women and 5.5 million males were estimated to have osteoporosis in Europe and 3.5 million new fractures were contained including 620.000 pelvic fractures, 520.000 vertebral fracture, 560.000 forensic breakthroughs and 1.800.000 fractures (Rodríguez, Valdivia, \& Trincado, 2007). In recent years, there have been reports suggesting a high prevalence of low vitamin $D$ intake and lack of vitamin D or insufficient vitamin D status in Europe (González, Alvarado, Rojas, Navarrete, Velásquez, \& Arteaga, 2007). This number is associated with an increase in health risk problems which is associated also with low decreased level of vitamin D.

The well-prescribed prevention of deficiency of vitamin D and osteomalacia is very important. But it may also have an implication of low vitamin D status in bone loss, muscle weakness and fracture reduction in humans. Although there is no agreement on optimal plasma vitamin D levels, it is apparent that the level of 25-hydroxyvitamin D [25 (OH) D] are often below the recommended intervals for the general population and are particularly low in some groups of the population, such as those in institutions (Mithal et al., 2009).

\section{Conclusion}

From the research study and the results we conclude that:

- Vitamin D level in women in menopausal period is lower than in the control patients and also the vitamin D level compared between winter time and summer time is around $10-15 \%$ lower in winter time.

- Permanent reduction with a high signaling reduces in progressively way the level of calcium paralysis with the vitamin $\mathrm{D}$ of all age groups investigated in comparison to the control patients

- Parathyroid hormone is a very important hormone in women who have a $12-15 \%$ increase of parathormone in patients with low level of vitamin $\mathrm{D}$ and decrease of calcium ions compared with control patients.

- $\quad$ From the survey of women in period of premenopause, menopause and postmenopause we conclude that the most common symptoms are in women with high body temperature. The other symptoms was insomnia, depression, bone pain, muscle pain etc.

From this study we suggest to all women to take more supplements of vitamin D especially in menopausal period. To visit their doctors as often they can, to control hormonal levels and to take a healthy diet.

\section{Conflict of interests}

The authors declare that there is no conflict of interests regarding the publication of this paper.

\section{References}

Bandeira et al. (2010). Vitamin D deficiency and its relationship with bone mineral density among postmenopausal women living in the tropics. Arq Bras Endocrinol Metabol, 54, 227-32. Based on WHO health Navigator.

González, G., Alvarado, J. N., Rojas, A., Navarrete, C., Velásquez, C. G., \& Arteaga, E. (2007). High prevalence of vitamin D deficiency in Chilean healthy postmenopausal women with normal sun exposure: Additional evidence for a worldwide concern. Menopause, 14, 455-61.

Holick et al. (2011). Endocrine Society Evaluation, treatment, and prevention of vitamin D deficiency: An Endocrine Society clinical practice guideline. J Clin Endocrinol Metab, 96, 1911-30.

Holick, M. F. (2007). Vitamin D deficiency. N Engl J Med., 357, 266-81.

IOM (Institute of Medicine). (2011). Dietary Reference Intakes for Calcium and Vitamin D. Committee to Review Dietary Reference Intakes for Calcium and Vitamin D. Washington DC: The National Academies Press. Institute of Medicine.

Mithal et al. (2009). IOF Committee of Scientific Advisors (CSA) Nutrition Working Group Global vitamin D status and determinants of hypovitaminosis D. Osteoporos Int., 20, 1807-20.

Rodríguez, P. J. A., Valdivia, C. G., \& Trincado, M. P. (2007). Vertebral fractures, osteoporosis and vitamin D levels in Chilean postmenopausal women. Rev Med Chil., 135, 31-6.

Russo, L. A., Gregório, L. H., Lacativa, P. G., \& Marinheiro, L. P. (2009). Concentration of 25-hydroxyvitamin D in postmenopausal women with low bone mineral density. Arq Bras Endocrinol Metabol, 53, 1079-87. 
Salamone, L. M., Dallal, G. E., Zantos, D., Makrauer, F., \& Dawson-Hughes, B. (1994). Contributions of vitamin D intake and seasonal sunlight exposure to plasma 25-hydroxvitamin D concentration in elderly women. Am J Clin Nutr., 58, 80-6.

Wahl et al. (2012). A global representation of vitamin D status in healthy populations. Arch Osteoporos, 7 , $155-72$.

Working Group of the Australian and New Zealand Bone and Mineral Society. (2005). Endocrine Society of Australia. Osteoporosis Australia Vitamin D and adult bone health in Australia and New Zealand: A position statement. Med J Aust., 182, 281-5.

\section{Copyrights}

Copyright for this article is retained by the author(s), with first publication rights granted to the journal.

This is an open-access article distributed under the terms and conditions of the Creative Commons Attribution license (http://creativecommons.org/licenses/by/4.0/). 